\title{
Bacterial toxic-shock syndrome
}

INSERM

\section{Source}

INSERM. (1999). Orphanet: an online rare disease and orphan drug data base. Bacterial toxic-shock syndrome. ORPHA:36234

Bacterial toxic shock syndrome (TSS) is a potentially fatal, acute disease characterized by a sudden onset of high fever along with nausea, myalgia, vomiting and multisystem organ involvement, potentially leading to shock and death. TSS is mediated by superantigenic toxins, usually caused by an infection with Staphylococcus aureus in staphylococcal TSS (see this term) or Streptococcus pyogenes in streptococcal TSS (see this term). 